\title{
DATE SYRUP AS A SUGAR SUBSTITUTE AND NATURAL FLAVOUR AGENT IN ICE CREAM MANUFACTURE Tammam, A. A. ${ }^{\text {a }}$; K. H. Salman ${ }^{\text {b }}$ and A. M. Abd-El-Rahim ${ }^{a}$ ${ }^{a}$ Dairy Science Department, Faculty of Agriculture, Assiut University, Egypt \\ ${ }^{\mathrm{b}}$ Dairy Science Department, Faculty of Agriculture, Al-Azhar University (Assiut), Egypt \\ Corresponding E-mail: aat@aun.edu.eg
}

\begin{abstract}
The addition of date syrup (Dibis) as a substitution of sugar in the ice cream manufacturing was replaced by $20,40,60$ and $100 \%$. The effect of these replacements on the titratable acidity, $\mathrm{pH}$, total solids, specific gravity, weight per gallon, viscosity in the ice cream mixes and the specific gravity, weight per gallon, overrun and melting rate as well as the sensory evaluation of the resultant ice cream were evaluated.

The titratable acidity of ice mixes increased significantly with the increase of date syrup while the specific gravity of plain ice cream was higher significantly than the mixes prepared with the addition of dibis. The replacement of sugar in ice cream mixes resulted in an increase significantly in viscosity and the increase was proportional to the replacement ratio of dibis.

The specific gravity as well as weight per gallon of resultant ice cream increased significantly with the increasing of sugar replacement by dibis. The overrun of the resultant ice cream decreased significantly as a result of replacing sugar by dibis. Regarding to the melting rate of resultant ice cream there was a significantly decrease of all treatment than the plain ice cream.

The average of total bacterial, psychrotrophic bacteria and moulds \& yeasts counts of mixes before pasteurization were higher than that after pasteurization in all treatments. On the other hand, the total bacterial, psychrotrophic bacteria and yeast \& mould counts of resultant ice cream were increased in all treatments.

It is recommended that the dibis can be used as replacement of sugar up to $60 \%$ to give good quality ice cream with enhancing the nutritive value of the products. Keywords: Ice cream, Dibis, Natural Flavouring and, Sensory quality.
\end{abstract}

\section{INTRODUCTION}

Ice cream and related products are generally aerated and characterized as frozen foams. The gas phase volume varies greatly from a high of greater than $50 \%$ to a low of $10-15 \%$ (Goff 2002). Ice cream contains $10-16 \%$ fat that is the main component affecting flavour and textural properties of the product. Milk fat interacts with other ingredients to develop the texture, mouthfeel, creaminess, and overall sensation of lubricity (Mahdian and Karazhian, 2013)

Date fruits assume great importance in human nutrition owing to their rich content of essential nutrients which include carbohydrates, salts, minerals, dietary fiber, vitamins, fatty acids, amino acids and protein. They have enormous scope and potential for use as food for generations to come due to their remarkable nutritional, health and economic value. The nutritional 
value of dates is due to their high sugar content, potassium, calcium, magnesium and iron as well as vitamins and Niacin. Further, dates are rich in sugar ranging from $65 \%$ to $80 \%$ on dry weight basis mostly of inverted form glucose and fructose (Lambiote, 1982).

Dibis is a date product obtained as an incidental by-product when bagged humid dates are heaped for several months. Also, it is produced on different scales by the extraction and boiling down of juice (FAO, 2004). Date syrup contains in addition to sugar, macro and micro elements particularly high iron content (Al-Khateeb, 2008).

Hamad et al., (1983) and Salama (2004) studied the use of date syrup as a sweetening and flavouring ingredient in ice cream manufacture. Acceptable product was obtained by replacing $50 \%$ of the sugar with date syrup and 40\%, respectively. Shukr and Muhsin (1984) showed that substitution of no more than $40 \%$ of sucrose in ice cream mix with date dibis produced acceptable product. The use of dates and date syrup as a sweeting agent increase the nutritive value of ice cream by fortifying it with proteins, minerals and vitamins (Yousef, 1976).

The functions of sweetening agents are to provide the desired level of sweet taste; as a source of food solids that contribute to the total solids content of the ice cream; as a means of controlling the freezing point and hence the stiffness of ice cream when discharged from the freezer and at any given storage temperature; and as a water binding agent to promote a smooth textured ice cream (Jimen ez-Flores et al., 1993).

The objective of this study was to evaluate the use of date syrup in different ratio to replace the sugar partially or completely in ice cream manufacture and their effect on some physical, microbiological and sensory characteristics of the products.

\section{MATERIALS AND METHODS}

\section{Materials}

Fresh cream (42\% fat) was separated from buffalo's milk, which was obtained from the herd of Assiut Governate. Skim milk powder-spray dried (96\% T.S.) was obtained from that imported from India. Date syrup (72\% T.S.) was prepared as described by Salman et al. (2012). Sucrose, and gelatin was obtained from the local market as well as the unicream 300 was obtained from the United Food Egypt.

\section{Preparation of ice cream mixes:}

Three replicates of six ice cream mixes treatments were prepared as described by Arbuckle (1986). The mixture consisted of $10 \%$ fat, $11 \%$ milk solid not fat (MSNF), $14 \%$ sugar, $0.5 \%$ gelatin and $0.3 \%$ unicream (control). The date syrup was added as sugar substitutions at 20, 40, 60 and $100 \mathrm{w} / \mathrm{w}$ with adding gelatin and unicream except for the treatments 5 and 6 . Furthermore, mixture which full substituted by date syrup was used to study the use of date syrup as stabilizer and emulsifiers substitutes. 


\section{Ice cream preparation and freezing:}

All ingredients were mixed together, heated at $80^{\circ} \mathrm{C}$ for $15 \mathrm{~min}$, cooled to $4^{\circ} \mathrm{C}$ and aged at this temperature overnight prior to freezing. The mixtures (3kg mix for each treatment) were frozen in ice freezing machine (CATTABRIGA spa, Italy). The resultant ice cream was packaged in cups $(120 \mathrm{ml})$ and put in deep freezer at $-20 \pm 2^{\circ} \mathrm{C}$ for hardening.

\section{Chemical Analysis:}

The moisture, fat, titratable acidity and $\mathrm{pH}$ were determined according to the official method A.O.A.C. (2002). The specific gravity of the mix was determined using the method described by Winton (1958). Viscosity of ice cream mix was carried out as reported by Arbuckle, (1986). Ice cream melting resistant and overrun was determined according to Arbuckle (1986). The sensory evaluation of resultant ice cream were assessed by 15 panelist, for flavor (50 points), body and texture (30 points), melting quality (10 points) and colour (10 points) as described by Salama (2004).

\section{Microbiological Analysis}

Total bacterial counts in the ice cream mixes and in the resultant ice cream were determined by the standard plate count technique as described by Marshal (1992). Coliform bacteria, psychrotrophic bacteria, and Yeasts \& moulds were enumerated according to the methods of IDF (1985a), IDF (1991) and IDF (1985b) respectively. Plates containing 20-200 colonies were counted, and the results expressed as colony forming units per gram ( $\left.\mathrm{cfu} \mathrm{g}^{-1}\right)$ of sample (IDF, 1991).

\section{Statistical Analysis}

Results were evaluated statistically using the software program; the SAS system for windows, release 8.02 TS level 02M0, SAS Institute Inc., Cary, NC, USA (SAS, 1999). Differences between means were determined by Duncan's multiple range tests at a level of 0.05 (Steel \& Torrie, 1980).

\section{RESULTS AND DISCUSSION}

\section{Properties of ice cream mixes:}

Table (1) illustrated the properties of ice cream mixes as affected by the different percentage ratio of sugar substitution by date syrup (dibis). The titratable acidity of ice cream mixes increased significantly $(p<0.05)$ with the increase of date syrup ratio while the $\mathrm{pH}$ values were decreased significantly $(p<0.05)$. These results are in agreement with those reported by Gudnason et al., (1960), Holland (1968), El-Sadek et al., (1974), Hamad et al., (1983) and Salama (2004).

Also, data in Table (1) revealed that the specific gravity of ice cream mixes was affected by the addition of dibis. It was observed that the specific gravity of plain ice cream higher significantly $(P<0.05)$ than the mixes prepared with the addition of dibis. The decrease significantly $(p<0.05)$ in the specific gravity of ice cream mixes with addition of dibis was proportional to the replacement ratio of dibis. It was decreased with the increasing of dibis ratio. 
Table (1): Some characteristics of ice cream mixes made by substitution of sucrose with different ratios of date syrup (Dibis).

\begin{tabular}{|c|c|c|c|c|c|c|}
\hline \multirow[b]{2}{*}{ Treatments } & \multicolumn{6}{|c|}{ Properties } \\
\hline & $\begin{array}{l}\text { Titratable } \\
\text { acidity \% }\end{array}$ & pH & \begin{tabular}{|l|} 
Total \\
Solids
\end{tabular} & $\begin{array}{c}\text { Sppecfic } \\
\text { gravity }\end{array}$ & $\begin{array}{l}\text { Weight } \\
\text { per } \\
\text { gallon }\end{array}$ & $\begin{array}{l}\text { Viscosity } \\
\text { (flow rate in } \\
\text { sec.) }\end{array}$ \\
\hline Control & $0.20^{d}$ & $6.24^{\mathrm{a}}$ & $36.57^{9}$ & $1.088^{\mathrm{a}}$ & $9.074^{\mathrm{a}}$ & $24^{t}$ \\
\hline T1 & $0.23^{\mathrm{C}}$ & $6.16^{\mathrm{b}}$ & $37.09^{\dagger}$ & $1.087^{D}$ & $9.070^{b}$ & $102^{d}$ \\
\hline T2 & $0.23^{c}$ & $6.06^{c}$ & $37.28^{\mathrm{C}}$ & $1.084^{\mathrm{C}}$ & $9.037^{\mathrm{C}}$ & $205^{\mathrm{C}}$ \\
\hline T3 & $0.25^{b}$ & $5.98^{\mathrm{d}}$ & $37.48^{b}$ & $1.079^{\mathrm{d}}$ & $9.000^{d}$ & $261^{b}$ \\
\hline $\mathrm{T} 4$ & $0.31^{a}$ & $5.89^{\dagger}$ & $37.58^{a}$ & $1.078^{\mathrm{e}}$ & $8.963^{\dagger}$ & $313^{\mathrm{a}}$ \\
\hline T5 & $0.30^{\mathrm{a}}$ & $5.93^{\mathrm{e}}$ & $37.44^{\mathrm{C}}$ & $1.075^{\dagger}$ & $8.986^{\mathrm{e}}$ & $88^{\mathrm{e}}$ \\
\hline T6 & $0.31^{a}$ & $5.81^{9}$ & $37.42^{\mathrm{d}}$ & $1.047^{9}$ & $8.728^{9}$ & $24^{\dagger}$ \\
\hline \multicolumn{2}{|l|}{ C:control } & \multicolumn{3}{|c|}{$\begin{array}{l}\text { T1: } 20 \% \text { replacement of } \\
\text { dibis }\end{array}$} & $\begin{array}{c}\text { T2: } 40 \% \\
\text { dibis }\end{array}$ & cement of \\
\hline \multicolumn{2}{|c|}{$\begin{array}{l}\text { T3: } 60 \% \text { replacement } \\
\text { of dibis }\end{array}$} & \multicolumn{3}{|c|}{$\begin{array}{l}\text { T4: } 100 \% \text { replacement } \\
\text { of dibis }\end{array}$} & \multicolumn{2}{|c|}{$\begin{array}{c}\text { T5: } 100 \% \text { replacement of } \\
\text { dibis+ unicream } \\
\text { without gelatin }\end{array}$} \\
\hline
\end{tabular}

It could be noticed that the replacement of sugar in ice cream mixes resulted in an increase significantly $(p<0.05)$ in viscosity and the increase was proportional to the replacement ratio of dibis. These results were in harmony with those reported by Kinsella (1984) and Kurultay et al. (2010). It could be observed that the viscosity values recorded by ice cream mixes by gelatin were higher significantly $(p<0.05)$ than that recorded in the plain ices cream mixes. While the viscosity of ice cream mixes without stabilizer gave the same value of plain ice cream mixes. The cause of higher viscosity is related to a higher water binding capacity of stabilizers (Kurultay et al., 2010). The replacement of sugar by dibis show significantly decrease $(p<0.05)$ in weight per gallon of ice cream mixes.

\section{Characteristics of the resultant ice cream:}

The characteristics of ice cream made by substitution of sugar with different ratios of date syrup (Dibis) were illustrated in Table (2). The specific gravity as well as weight per gallon of resultant ice cream increased significantly $(p<0.05)$ with the increasing of sugar replacement by dibis. It observed from data in Table (2) that the overrun of the resultant ice cream decreased significantly $(p<0.05)$ as a result of increase the replacing of sugar by dibis. The decreasing in the overrun may be attributed to unproper excess viscosity which caused decreasing the whipping ability of ice cream mix (Arbuckle, 1986 and Salama, 2004). 
Table (2): Some characteristics of ice cream made by substitution of sucrose with different ratios of date syrup (Dibis).

\begin{tabular}{|l|c|c|c|c|}
\hline \multirow{2}{*}{ Treatments } & \multicolumn{4}{|c|}{ Properties } \\
\cline { 2 - 5 } & Sp.gr. (g/cm $)$ & $\begin{array}{c}\text { Weight per } \\
\text { gallon }\end{array}$ & Overrun & $\begin{array}{c}\text { Melting rate } \\
\text { (min) }\end{array}$ \\
\hline Control & $0.734^{\mathrm{g}}$ & $6.124^{\mathrm{g}}$ & $48.143^{\mathrm{a}}$ & $65^{\mathrm{a}}$ \\
\hline T1 & $0.783^{\mathrm{f}}$ & $6.527^{\mathrm{t}}$ & $38.965^{\mathrm{b}}$ & $35^{\mathrm{e}}$ \\
\hline T2 & $0.795^{\mathrm{e}}$ & $6.633^{\mathrm{e}}$ & $36.251^{\mathrm{c}}$ & $40^{\mathrm{d}}$ \\
\hline T3 & $0.830^{\mathrm{b}}$ & $6.921^{\mathrm{b}}$ & $30.056^{\mathrm{e}}$ & $44^{\mathrm{c}}$ \\
\hline T4 & $0.802^{\mathrm{d}}$ & $6.686^{\mathrm{d}}$ & $34.070^{\mathrm{d}}$ & $55^{\mathrm{b}}$ \\
\hline T5 & $0.846^{\mathrm{a}}$ & $7.057^{\mathrm{a}}$ & $27.334^{\dagger}$ & $31^{\dagger}$ \\
\hline T6 & $0.825^{\mathrm{c}}$ & $6.883^{\mathrm{c}}$ & $26.803^{\mathrm{g}}$ & $28^{\mathrm{g}}$ \\
\hline
\end{tabular}

Regarding to the melting rate of resultant ice cream as described in Table (2) there was a significantly $(p<0.05)$ decreasing of all treatment than the plain ice cream. In the same time, the melting rate values were increased significantly $(\mathrm{p}<0.05)$ by increasing the substitution of sugar by dibis more than $20 \%$. These results in agreement with those reported by Salama (2004). Microbiological quality of ice cream mixes and resultant ice cream.

From the data represented in Tables ( 3 and 4 ), it could be seen that the average of total bacterial, psychrotrophic bacteria and moulds \& yeasts counts of mixes before pasteurization were higher than the values after pasteurization in all treatments. This was due to the killing effect of pasteurization process (Arbuckle, 1986 and Abd El-Rahim, 1999). Also, it was noticed that the average of total bacterial, psychrotrophic bacteria and moulds \&yeasts counts were increased after aging. Regulation on the quality of ice cream, Official Standard of Egypt, No 1185/2005 was issued, were specified as follows: total plate count (TPC) should be less than 150,000 $\mathrm{CFU} / \mathrm{gm}$. The results of this study were in agreement with this regulation.

Table (3): Microbiological quailty of ice cream mixes made by substitution of sucrose with different levels of date syrup (Dibis).

\begin{tabular}{|c|c|c|c|c|c|c|c|c|c|c|}
\hline \multirow[b]{2}{*}{$\begin{array}{l}\text { Treatment } \\
\text { s }\end{array}$} & \multicolumn{3}{|c|}{ Total plate count } & \multicolumn{3}{|c|}{ Psychrotrophic bacteria } & \multicolumn{3}{|c|}{ Yeast and mould } & \multirow{2}{*}{$\begin{array}{l}\text { Coliform } \\
\text { bacteria }\end{array}$} \\
\hline & Before & After & $\begin{array}{l}\text { After } \\
\text { aging }\end{array}$ & Before & After & $\begin{array}{l}\text { After } \\
\text { aging }\end{array}$ & Before & After & $\begin{array}{l}\text { After } \\
\text { aging }\end{array}$ & \\
\hline Control & $98 \times 10^{4}$ & $48 \times 10^{2}$ & $73 \times 10^{3}$ & $41 \times 10^{4}$ & $30 \times 10^{2}$ & $33 \times 10^{3}$ & $19 \times 10^{2}$ & $11 \times 10^{2}$ & $14 \times 10^{2}$ & ND \\
\hline $\mathrm{T} 1$ & $95 \times 10^{4}$ & $50 \times 10^{2}$ & $75 \times 10^{3}$ & $38 \times 10^{4}$ & $21 \times 10^{2}$ & $25 \times 10^{3}$ & $23 \times 10^{2}$ & $15 \times 10^{2}$ & $17 \times 10^{2}$ & ND \\
\hline T2 & $93 \times 10^{4}$ & $43 \times 10^{2}$ & $65 \times 10^{3}$ & $37 \times 10^{4}$ & $19 \times 10^{2}$ & $41 \times 10^{2}$ & $24 \times 10^{2}$ & $17 \times 10^{2}$ & $18 \times 10^{2}$ & ND \\
\hline T3 & $88 \times 10^{4}$ & $31 \times 10^{2}$ & $51 \times 10^{3}$ & $34 \times 10^{4}$ & $18 \times 10^{2}$ & $38 \times 10^{2}$ & $24 \times 10^{2}$ & $16 \times 10^{2}$ & $19 \times 10^{2}$ & ND \\
\hline T4 & $86 \times 10^{4}$ & $22 \times 10^{2}$ & $33 \times 10^{3}$ & $32 \times 10^{4}$ & $15 \times 10^{2}$ & $35 \times 10^{2}$ & $22 \times 10^{2}$ & $14 \times 10^{2}$ & $18 \times 10^{2}$ & ND \\
\hline T5 & $84 \times 10^{4}$ & $18 \times 10^{2}$ & $24 \times 10^{2}$ & $31 \times 10^{4}$ & $11 \times 10^{2}$ & $16 \times 10^{2}$ & $21 \times 10^{2}$ & $13 \times 10^{2}$ & $16 \times 10^{2}$ & ND \\
\hline T6 & $62 \times 10^{4}$ & $19 \times 10^{2}$ & $14 \times 10^{2}$ & $29 \times 10^{4}$ & $9 \times 10^{2}$ & $8 \times 10^{2}$ & $18 \times 10^{2}$ & $9 \times 10^{2}$ & $14 \times 10^{2}$ & ND \\
\hline
\end{tabular}

Before": before pasteurization After":after pasteurization ND": not detected

On the other hand, the total bacterial, psychrotrophic bacteria and yeasts \& moulds counts of resultant ice cream were slightly increased in all treatments after aging (Table, 4). This may be attributed to the incorporated air during whipping process of the pasteurized ice cream mix. These results 
were in agreement with those reported by Leznik (1956) and Abd El-Rahim (1999). Also, it is observed from the Tables ( 3 and 4) that the coliform bacteria not detectable before and after pasteurization in the ice cream mix and also in the resultant ice cream. This is may be due to the severity of heat treatments of ice cream mixes. These results are in harmony with those of Abd El-Rahim (1999)

Table (4): Microbiological characteristics of ice cream made by substitution of sucrose with different ratios of date syrup (Dibis)

\begin{tabular}{|c|c|c|c|c|}
\hline \multirow[b]{2}{*}{ Treatments } & \multicolumn{4}{|c|}{ Properties } \\
\hline & $\begin{array}{c}\text { Total plate } \\
\text { count }\end{array}$ & $\begin{array}{l}\text { Psychrotrophic } \\
\text { bacteria }\end{array}$ & $\begin{array}{l}\text { Yeast and } \\
\text { mould }\end{array}$ & $\begin{array}{l}\text { Coliform } \\
\text { bacteria }\end{array}$ \\
\hline Control & $91 \times 10^{3}$ & $98 \times 10^{2}$ & $19 \times 10^{2}$ & ND \\
\hline T1 & $94 \times 10^{3}$ & $82 \times 10^{2}$ & $20 \times 10^{2}$ & ND \\
\hline T2 & $86 \times 10^{3}$ & $32 \times 10^{2}$ & $24 \times 10^{2}$ & ND \\
\hline T3 & $74 \times 10^{3}$ & $18 \times 10^{2}$ & $23 \times 10^{2}$ & ND \\
\hline T4 & $65 \times 10^{3}$ & $14 \times 10^{2}$ & $20 \times 10^{2}$ & ND \\
\hline T5 & $65 \times 10^{3}$ & $8 \times 10^{2}$ & $19 \times 10^{2}$ & ND \\
\hline T6 & $64 \times 10^{3}$ & $4 \times 10^{2}$ & $20 \times 10^{2}$ & ND \\
\hline
\end{tabular}

\section{Sensory evaluation}

The results of the sensory evaluation of the resultant ice cream as affected by replacement of sugar by date syrup were exerted in Table (5). It was noticed that the average of total scoring points of plain ice cream gained the highest values followed by the treatment of ice cream substitution of sugar with $60 \%$ date syrup (dibis). While the resultant ice cream with substitution of sugar $100 \%$ by date syrup gained the lowest values.

Table (5): Sensory properties of ice cream made by substitution of sucrose with different ratios of date syrup (Dibis)

\begin{tabular}{|l|c|c|c|c|c|}
\hline \multirow{2}{*}{ Treatments } & \multicolumn{5}{|c|}{ Properties } \\
\cline { 2 - 6 } & Flavour & $\begin{array}{c}\text { Body and } \\
\text { Texture (30) }\end{array}$ & $\begin{array}{c}\text { Melting } \\
\text { properties } \\
\mathbf{( 1 0 )}\end{array}$ & Colour (10) & Total (100) \\
\hline Control & 45.71 & 27.64 & 9.36 & 9.43 & 92.14 \\
\hline T1 & 42.35 & 25.59 & 8.41 & 7.18 & 83.53 \\
\hline T2 & 42.13 & 27.20 & 9.07 & 7.60 & 86.00 \\
\hline T3 & 43.63 & 26.89 & 8.44 & 7.23 & 86.19 \\
\hline T4 & 41.20 & 26.67 & 8.33 & 6.93 & 83.13 \\
\hline T5 & 41.07 & 25.40 & 8.13 & 7.07 & 81.67 \\
\hline T6 & 38.13 & 24.67 & 7.40 & 6.87 & 77.07 \\
\hline
\end{tabular}

The foregoing results indicated possibility of using dibis in the ice cream manufacturing in partial substations of sugar up to $60 \%$ and as a flavoring agent in ice cream manufacturing. Moreover, date syrup (dibis) will add to the nutritional values of finished products. 


\section{REFERENCES}

A.O.A.C., Association of Official Analytical Chemists (2000). Official Methods of Analysis of Association of Official Agriculture Chemists. Wisconsin: George Banta Co. Inc.

Abd El-Rahim, A.M. (1999). Utilization of some ingredients in the manufacture of ice cream. M.Sc. Thesis, Faculty of Agriculture, Assiut University.

Al-Khateeb, A. A. (2008). Enhancing the growth of date palm (Phoenix Dactylifera) in vitro tissue by adding date syrup to the culture medium. Sci. J. King Faisal Univ. (Basic Appl. Sci.) 19: 71.

Arbuckle, W.S. (1986). Ice cream. $4^{\text {th }}$ Ed., the AVI publishing Co. Inc. West Port. Connecticut, USA.

Egyptian Standards for Ice Cream. (2005). Milk and water ice (Ice Cream) Part: 1 Milk Ice , ES: 1185-1/2005. Ministry of Industry and Technological Development, Egypt.

El-Sadek, G.M., Moneib, A. and Farag, A.H. (1974). Sterilized flavoured milk drinks. 1. Dates-flavoured buffalo milk. J. of Dairy Sci. 2:105.

FAO (2004). Date palm production chapter 1 and 2 downloaded from FAO website: www.FAO.org on 2007/05/24.

Goff, H.D. (2002). Formation and stabilization of structure in ice- cream and related products. Curr. Opin. Colloid Interface Sci. 7: 432.

Gudnanson, C.V., Holland, R.E. and Shipe, W.F. (1960). Fruit flavoured milk. American Milk Rev. 32:4.

Hamad, A.M., Mustafa, A.I. and M.S. Al-Kahtani (1983). Possibility of utilizing date syrup as a sweetening and flavouring agent in ice-cream making. Proceedings of the $1^{\text {st }}$ International Symposium on Date palm. King Faisal University, Saudi Arabia, March: 544.

Holland, R.F. (1958). Flavoured milk drinks. American Dairy Rev. 30:77.

IDF. (1985a). Milk and milk products. Enumeration of coliforms colony counts technique and most probable number technique at $30^{\circ} \mathrm{C}$. International Dairy Federation standard 73A.

IDF. (1985b). Milk and milk products. Detection and enumeration of yeasts and moulds. International Dairy Federation standard 94A.

IDF. (1991). Milk. Enumeration of psychrotrophic microorganisms. Colony count technique at $6.5^{\circ} \mathrm{C}$. International Dairy Federation standard 101A.

Jimenez-Flores, R., Klipfel, N.J. and Tobias, J. (1993). Ice Cream and Frozen Desserts. pp: 59-157. In: Dairy Science and Technology Handbook. 2. Product Manufacturing. Y. K Hui (ed.). Wiley-VCH, Inc.

Kinsella, J.E. (1984). Milk proteins: Physicochemical and functional properties. Crit. Rev. Food Sci. Nutr. 21: 197-262.

Kurultay, S., Öksüz, Ö. and Gökcebag, Ö. (2010). The influence of different total solid, stabilizer and overrun levels in industrial ice cream production using coconut oil. Journal of Food Processing and Preservation 34: 346 . 
Lambiote, B. (1982). Some aspects of the role of dates in human nutrition. Proceedings of the $1^{\text {st }}$ International Symposium on Date Palm. King Faisal University, Saudi Arabia, March: 23.

Leznik, A.I. (1956). Bacteriological quality of ice cream. Vop. Pitan., 15 (2):57. (C.A. Dairy Sci. Abst., 18(6):504).

Mahdian, E. and R. Karazhian (2013). Effects of Fat Replacers and Stabilizers on Rheological, Physicochemical and Sensory Properties of Reduced-fat Ice Cream. J. Agr. Sci. Tech. 15: 1163.

Marshall, R.T. (1992). Standard Methods for Examination of Dairy Products, 16th ed. American Public Health Association Washington, D.C.

Salama, F.M.M. (2004). The use of some natural sweeteners in ice cream manufacture. J. of Dairy Sci., 32:355.

Salman, K.H., Mansour, A. I. A., Tammam, A. A. and El-Gazzar, F. E. (2012). Utilization of Egg-shell Powder as a Calcium Fortifier in Stirred Dibis Probiotic Yoghurt. Assiut J. Agric. Sci., 43:1.

SAS. (1999). Statistical analysis system, User's guide for personal computers, Version 8.2 Edition SAS Institute, Cary, N.C.

Shukr, M.M. and Muhsin. A.A. (1984). Utilization of date juice in some frozen desserts. J. Date Palm, 3:2.

Steel, R. G. D. and Torrie, J. H. (1980). Principles and Procedures of Statistics. New York, NY: McGraw-Hill Book Co., Inc.

Winton, A.L. (1958). Analysis of Foods. John Wiley and Sons Inc., New York, 3rd Printing.

Yousef, A.K. (1976). Nutritive value of commercial Iraqi dates. 2-Vit. Content. Palm and Dates Res. Center. Tech. Bull. 5/78 Beghdad. Iraq. 